\title{
Role of Victims in Criminal Action of Rape Against Children in Pemalang State Court
}

\section{R. Ayu Miya Ratih Ardhya Garini ${ }^{*}$ and Sri Kusriyah ${ }^{* *}$}

*) Students of Master of Law, Faculty of Law, Universitas Islam Sultan Agung Semarang, E-mail: Ratihardyaa@gmail.com

**) Lecturer of Master of Law, Faculty of Law, Universitas Islam Sultan Agung Semarang

\begin{abstract}
.
This study aims to analyze the role of the victim considered by the judge in deciding criminal cases of rape against children and the role of victims against children influences the imposition of criminal sanctions by judges at the Pemalang District Court. This research was conducted using a sociological juridical approach with the research specifications used in this research is descriptive in nature equipped with a case study of aspects of the role of the victim in considering the severity of the punishment given to the perpetrator of rape against children in Pemalang District Court, that children also have role in the occurrence of the crime of rape, whether the victim is active, passive, provocative, consciously or unconsciously. Based on the results of the research, it was concluded that the Pemalang District Court Judge had considered the aspects of the role of the victim in the criminal case of rape against children, that the role of the victim in the crime of rape against children was something that mitigated the crime imposed on the perpetrator.
\end{abstract}

Keywords: Role of Victim, Crime of Rape, Children.

\section{Introduction}

Along with the advancement of culture and science and technology, human behavior in social and state life is actually increasingly complex and even multicomplex. Such behavior when viewed from a legal perspective, of course, there are behaviors that can be categorized according to the norms and there are behaviors that are not in accordance with the norms. Against behavior in accordance with applicable norms (law), it is not a problem. Behavior that is not in accordance with the norm can usually cause problems in the field of law and harm the community. Behavior that is not in accordance with the norms or can be referred to as deviations from the agreed norms actually causes disruption of the order and peace of human life. Such fraud is usually labeled by the community as an offense or even as a crime. Crime in human life is a social phenomenon that every human being, society and even the state will always face. The fact has proven that crime can only be prevented and reduced, but it is difficult to eradicate completely. ${ }^{1}$

Indonesian country is a state based on law (rechstaat) in which Pancasila and the 1945 Constitution of the Republic of Indonesia are the most essential legal basis in addition to other legal products.

Law is often seen as a very complex social phenomenon. Initially this view was expressed by people who were unfamiliar with the law, in the sense that they

\footnotetext{
${ }^{1}$ Bambang Waluyo. (2004). Pidana dan Pemidanaan. Jakarta: Sinar Grafika. p.1
} 
had never experienced legal education. They are people whose lives are governed by law, but sometimes only know about it, if something goes wrong. There are parties who view the law as an attitude of action or regular behavior (steady). The method of thinking he uses is inductive-empirical, so that he sees the law as an attitude of action that is repeated in the same form, which has a specific goal, namely to achieve peace through harmony between order and tranquility, or between discipline and freedom. ${ }^{2}$

Constitutionally, the structure and organization of the Indonesian judicial system can be seen in the provisions of Article 24 of the 1945 Constitution of the Republic of Indonesia Amendments and organic laws regulating judicial power. Article 24 paragraph (2) states that "judicial power is exercised by a Supreme Court and judicial bodies under it in the environment of general courts, religious courts, military courts, state administrative courts and by a Constitutional Court". According to Article 24 paragraph (2) of the 1945 Constitution of the Republic of Indonesia, the Supreme Court is the pinnacle of justice. Further confirmation is contained in Article 20 paragraph (1) of Law no. 48 of 2009 concerning Judicial Power (UUKK) that the Supreme Court is the highest state court of the four judicial circles. The Supreme Court as the pinnacle of the judiciary has consequences for the one roof system in the administration of the judicial system in Indonesia. So that the judicial guidance and organizational structure, personnel administration and financial problems of the judiciary under it are in the Supreme Court. (Article 13 paragraph (1) KK Law). ${ }^{3}$

The author in this case will only discuss the role of the child as a victim in the occurrence of a criminal act of rape against a child whose definition is as described in Article 76 D and Article 81 paragraph (2) of Act No. 35 of 2014 concerning Amendments to Act No. 232002 concerning Child Protection which specifically has elements, namely requiring the necessity of intercourse with children which begins with alternative acts of violence or threats of violence or deliberately deception, a series of lies, or persuading children to have sexual intercourse.

The victims in certain situations and conditions can also invite the perpetrator to commit crimes against him due to his attitude and actions. In this case, the victim and the perpetrator had no prior relationship. For example, the victim behaves and acts negligently with his property (placing or carrying valuables without trying to secure them) so as to provide opportunities for others to take them without permission. It could also be due to the attitude and behavior of the victim, causing hatred, resentment and actions that are detrimental to the victim. It could also be because the victim is in a vulnerable area or is on duty in the security sector. The victim's party allows it, making it easier for him to become the target of evil deeds. ${ }^{4}$

\footnotetext{
2 Soerjono Soekanto. (1988). Efektifitas Hukum dan Peranan Sanksi. Bandung: Remadja Karya. p.1

3 Achmad Budi Waskito, Implementasi Sistem Peradilan Pidana Dalam Perspektif Integrasi, Vol. 1. No. 1 March 2018, http://jurnal.unissula.ac.id/index.php/RH/article/view/2648/1992

4 Rena Yulia. (2010). Viktimologi Perlindungan Hukum Terhadap Korban Kejahatan. Yogyakarta: Graha Ilmu. p. 77.
} 
In the view of traditional criminology, the explanation of the causes of a crime is always oriented towards the perpetrator. Due to this condition, victimology has tried to correct the unbalanced view by giving an explanation that in certain conditions and situations a person becomes a victim because the victim plays a role in it. In other words, in the occurrence of a criminal act the victimology sees as a result of the interaction process (at least) of two parties consisting of the perpetrator and the victim. ${ }^{5}$

In line with the aforementioned view, Anttila said that victimology will balance the stereotypes that have been used in perpetrator-oriented criminology in explaining the occurrence of a crime. In Anttila's view, it is further said that through victimology the perpetrators and victims can be seen as having elements as provocateurs and are easily provoked. 6

J.E Sahetapy also argues that criminology and victimology are interrelated sides of the coin. Attention to the crime that exists should not only revolve around the emergence of crime but also the consequences of crime, because from this it will appear that attention shifts not only to the perpetrator of the crime but also to the position of the victim of the crime. This is also discussed by other legal experts in paying attention to this relationship or at least the attention to the occurrence of crime not only from one point of view, if a person becomes a victim of a crime, it is clear that a crime has occurred, or there is a victim of crime and there is a crime there is a victim. So if you want to describe and prevent crime, you must pay attention to and understand the victims of a crime. ${ }^{7}$

In relation to criminal law, the development of victimology is closely related to the development of criminology, victimology shifts the old criminology study from the causal factors of crime to criminals to a new criminology study (victimology) which leads to a relationship, namely the relationship between the perpetrator of the crime and the victim. The results of a new criminology / victimology study have opened up a new perspective on the process of the occurrence of certain crimes (personal crimes), namely that crimes occur as a result of the interaction between the perpetrator and the victim in which the crime victim has a share in the process of occurring small to large crimes. ${ }^{8}$

In the Criminal Justice System, it culminates in the "verdict" or "verdict '. Judges are essentially studied from a theoretical perspective and judicial practice often creates disparities in terms of punishment (sentencing of disparity) and also correlates with" criminal policies ", where formulative policies are strategic and decisive policies. for applicable policies. ${ }^{9}$

\footnotetext{
5 Andrew Karmen. (1984). Crime Victims an introduction to Victimology, Books/Cole publishing Company Monterey, California. p. 73.

6 Inker Anttila, 1986, From Crime Policy to Victim Policy. Ezzat a.Fattah (Ed) dalam From Crime Policy to Victim Policy, Reorienting the Justice System, Macmilan Press Ltd. London, halaman 238, dalam Disertasi Angkasa, 2004, Kedudukan Korban dalam Sistem Peradilan Pidana (Pendekatan Viktimologis terhadap Korban Tindak Pidana Perkosaan) Disertasi, Universitas Diponegoro Semarang, p. 82.

${ }^{7}$ https://jantukanakbetawi.wordpress.com/2010/12/28/makalah-viktimologi

${ }^{8}$ Mudzakkir, Makalah disampaikan pada "Pelatihan Hukum Pidana dan Kriminologi: Kerjasama Fakultas Hukum UGM dan Masyarakat Hukum Pidana dan Kriminologi Indonesia (MAHUPIKI) di University Club UGM Yogyakarta, 23-27 Februari 2014, p. 4.

${ }^{9}$ Neil C. Chamelin, et.al, (1975). Introduction to Criminal Justice, Prentice-Hall, New Jesrsey. p. 1.
} 
The purpose of this study was to analyze the role of the victim being considered by the judge in deciding criminal cases of rape against children in Pemalang District Court and to analyze the extent to which the role of victims of child rape affects the imposition of criminal sanctions by judges at Pemalang District Court.

\section{Research methods}

The approach method used is sociological juridical (socio-legal research) ${ }^{10}$ with a qualitative research type. The research specification used in this research is descriptive in nature, because it tries to describe in detail the role of victim precipitation considered by the judge in deciding cases of rape against children in the jurisdiction of Pemalang District Court.

This study used a variety of relevant data sources in the form of primary data sources, namely from informants consisting of Judges, Legal Counsels (Advocates), inmates, and former perpetrators of the crime of rape against children and secondary data sources, namely data obtained indirectly from object of research. Data collection techniques in this study used a variety of methods or relevant ways, namely interviews, observations, literature studies and field studies in accordance with the types of data required. The collected data were analyzed qualitatively with an inductive line of thought. Regarding data in the form of information, the description is linked to other data to get clarity on a truth or vice versa so as to obtain a new picture or strengthen an existing picture and vice versa. $^{11}$

\section{Results and Discussion}

\subsection{Consideration of aspects of the role of the victim in the criminal act of rape of children by the judge}

Because the cases that are the object of research in this paper are children as victims of the criminal act of rape, the author will not clearly state the identity of the victim and the author will only use the initials against the identity of the victim in this study Decision Number 07 / Pid.Sus / 2015 / PN Pml.

From several legal facts in the case, it was clear that the role of the victim, namely the victim (witness PLM) and his friend, Refika, always came to the Defendant, and initially when the Defendant asked the PLM witness to have intercourse and the Defendant said he was responsible, the PLM witness easily agreed with the Defendant's wishes, and repeated incidents up to the fourth intercourse, where the PLM witness always came to the Defendant, besides that the PLM witness was also no longer awkward to have intercourse. various styles, and what was interesting was that the PLM witness always felt satisfied having intercourse with the Defendant.

\footnotetext{
10 Ronny Hanitjo Soemitro. (1985). Metodologi Penelitian Hukum, Jakarta: Ghalia Indonesia, p.13-14. 11 P. Joko Subagyo. (2004). Metodologi Penelitian Dalam Teori dan Praktek, Jakarta: Cetakan ke-IV, Rineka Cipta. p.106.
} 
The active role of the victim is also supported by the testimony of the PLM witness himself who testified (the testimony of the PLM witness) that he loved the Defendant and the Defendant had never threatened or seduced the witness to have intercourse, but in this case the Judge considered that the Defendant had committed the act of "cajoling" (one of the sub -element Article $76 \mathrm{D}$ jo Article 81 paragraph (2) of Act No. 35 of 2014 concerning Amendments to Act No. 23 of 2002 concerning Child Protection) to have sex with witnesses PLM. In addition, one of the things that according to the author was a factor behind the victim's activeness was that the PLM witness had previously had intercourse with another person when he was in junior high school so that he already knew how the situation and how it felt to have intercourse and according to the author the quantification of the Defendant's actions in this case. is a criminal act of rape against a child even though the victim's witness wants and enjoys the rape.

The interaction pattern shown between the victim (PLM) and the perpetrator (Candra alias Ican bin Lili Rusmana) is so close that it can accelerate victimization, in this case the author believes that the victim, who is still in the category of being a child, can be blamed for his activeness in creating situations and circumstances. so that the criminal act of rape against him even the victim wants and enjoys rape committed by the perpetrator against him. Based on this, Viano's theory ${ }^{12}$ (1976) who saw the victim not only as a passive object as an innocent part of the crime, but sometimes the victim played an active role. The fact that the victim also wants the crime to occur is also in line with Von Hentig's opinion. ${ }^{13}$ The crime occurred because it was what the victim wanted.

\subsection{The influence of the role of the victim in the criminal act of rape against children on the imposition of criminal sanctions.}

According to Judge Popop Rizanta T's opinion, that we do not deny the development of legal knowledge in a more complex direction as the dynamic development of human civilization. Such is the case with the development of knowledge about victims, where the role of the victim in the occurrence of a criminal act of rape against a child will be considered by the Judge in making his decision, as long as the main elements as outlined in Article 197 paragraph 1 of the Criminal Procedure Code are fulfilled, even though the objectives of the Protection Law. Children are to protect children from crime, but it cannot be denied that today, technological developments and the fading of eastern cultural values increasingly make children feel more and more mature and perceive a sexual relationship as not something to be afraid of anymore, even though it is clear that sexual relations are among them. Underage children are strictly prohibited, and the role of children in the crime of rape is generally increasing due to many factors that cause it. ${ }^{14}$

\footnotetext{
12 Andrew Karmen. (1984). Crime Victims an introduction to Victimology, California: books/Cole publishing Company monterey.

13 G.Widiartana. (2014). Viktimologi Perpektif Korban Dalam Penanggulangan Kejahatan, Yogyakarta: Cahaya Atma Pustaka.

14 Interview with Popop Rizanta, SH.MH, Chairman of the Pemalang District Court, on Thursday, August 6, 2015.
} 
According to Judge Wisnu Widodo and Judge Silvera Chintia Dewi, it is very rare for Judges in making a decision to consider aspects of the role of the victim, because usually Judges are more focused on aspects of the Defendant's actions and their mistakes and losses to the victim, attention to the role of the victim in a criminal case needs to be considered so that there is a balance in the punishment in relation to the severity of the punishment to be imposed. ${ }^{15}$

Each court decision must be accompanied by material considerations which become the legal basis and reasons for the decision. This is in Article 14 paragraph (2) of Act No. 48 of 2009, according to Article 1 point 11 of Act No. 8 of 1981 concerning the Criminal Procedure Code (KUHAP), which states that court decisions are statements of Judges who uttered in an open court session, which can be in the form of imprisonment or freedom or freedom from all charges in matters and methods regulated by this law. Judges in their considerations must also pay attention to things that are burdensome and mitigate as mentioned in Article 8 paragraph (2) of Act No. 48 of 2009, this makes it easier for judges to settle cases because they not only convey legal voices but can make legal findings from various legal sources. inventions and can also create laws because they actually exist in society. Where there is a community there is of course the law, it remains how we strive for law enforcement to truly fulfill a sense of justice in society. If you make legal discoveries based on the value of justice in deciding cases and then the judge's decision becomes law, a law will be created that is truly in line with the values of justice in society.

\section{Closing}

That the aspects of the role of the victim in the criminal case of child rape by the Judge at the Pemalang District Court have currently been considered in establishing the law with objective legal arguments based on the victimology side of the severity of the punishment imposed, here the judge is not only oriented towards criminal orientation (actor-oriented), but has considered the law from a victimoriented perspective without prejudice to the purpose of Act No. 35 of 2014 concerning Amendments to Act No. 23 of 2002 concerning Child Protection, namely to protect children from crime. Judges in handling cases of rape of children as crimes that have a serious impact on the future of the victim, should impose the fairest possible sentence in accordance with the applicable law on the perpetrator as well as taking into account the interests of the victim in all its dimensions.

\section{References}

\section{Journals:}

[1] Achmad Budi Waskito, Implementasi Sistem Peradilan Pidana Dalam Perspektif Integrasi, Vol. 1. No. 1 March 2018,

\footnotetext{
15 Interview with Wisnu Widodo, SH. and Silvera Chintia Dewi, both Judges at Pemalang District Court, on Wednesday, August 12, 2015. Compare this with the results of Angkasa's research which is stated in his dissertation which suggests a new paradigm in the criminal justice system, namely the victim-criminal oriented paradigm, as a new paradigm replacing the criminal paradigm oriented (Angkasa, 2004, Op.cit. p. 283).
} 
http://jurnal.unissula.ac.id/index.php/RH/article/view/2648/1992

[2] Handika Naufal Husni, The Role of Judges Based on Considerations of Community Cultural Values to Create Justice, Vol 2, No 4 (2020), http://jurnal.unissula.ac.id/index.php/ldj/article/view/13692/5209

\section{Books:}

[1] G.Widiartana. (2014). Viktimologi Perpektif Korban Dalam Penanggulangan Kejahatan, Yogyakarta: Cahaya Atma Pustaka.

[2] Inker Anttila. (1986). From Crime Policy to Victim Policy. Ezzat a.Fattah (Ed) dalam From Crime Policy to Victim Policy, Reorienting the Justice System, Macmilan Press Ltd. London, halaman 238, dalam Disertasi Angkasa, 2004, Kedudukan Korban dalam Sistem Peradilan Pidana (Pendekatan Viktimologis terhadap Korban Tindak Pidana Perkosaan) Disertasi, Universitas Diponegoro Semarang.

[3] Irawan Soehartono. (1999). Metode Penelitian Sosial Suatu Tehnik Penelitian Bidang Kesejahteraan Sosial Lainnya. Bandung: Remaja Rosda Karya.

[4] Mudzakkir, Makalah disampaikan pada "Pelatihan Hukum Pidana dan Kriminologi: Kerjasama Fakultas Hukum UGM dan Masyarakat Hukum Pidana dan Kriminologi Indonesia (MAHUPIKI) di University Club UGM Yogyakarta, 23-27 Februari 2014.

[5] Neil C. Chamelin, et.al, (1975). Introduction to Criminal Justice, Prentice-Hall, New Jesrsey.

[6] P. Joko Subagyo. (2004). Metodologi Penelitian Dalam Teori dan Praktek, Jakarta: Cetakan ke-IV, Rineka Cipta.

[7] Rena Yulia. (2010). Viktimologi Perlindungan Hukum Terhadap Korban Kejahatan. Yogyakarta: Graha Ilmu

[8] Ronny Hanitjo Soemitro. (1985). Metodologi Penelitian Hukum, Jakarta: Ghalia Indonesia.

[9] Soerjono Soekanto. (1988). Efektifitas Hukum dan Peranan Sanksi. Bandung: Remadja Karya.

[10] Soeryono Soekanto. (1984). Pengantar Penelitian Hukum. Jakarta: UI Press.

\section{Internet:}

[1] https://jantukanakbetawi.wordpress.com/2010/12/28/makalah-viktimologi 